\title{
Hyperthermia after cardiac surgery
}

Kazuo Abe MD,
Yuji Miyamoto $M D$,
Kenji Ohnishi $\mathrm{MD}^{\star}$

Purpose: To describe two cases of hyperthermia occurning after cardiac surgery.

Clinical features: At the end of cardiopulmonary bypass, protamine was injected to reverse heparin. Following protamine. hypotension. pulmonary hypertension and hypoxia developed, but protamine induced hypotension recovered after administration of methyl predonisolone and catecholamines. Rectal temperature increased to $41^{\circ} \mathrm{C}$ in the first case and $40^{\circ} \mathrm{C}$ in the second after recovery from protamine induced hypotension. Arterial blood gas analysis, breathing 100\% oxygen, showed severe acidosis and hypercapnia $(\mathrm{pH} 6.96, \mathrm{PaCO}, 73 \mathrm{mmHg}$. $\mathrm{PaO}, 45 \mathrm{mmHg}, \mathrm{BE}-18$ in the first case, and $\mathrm{pH} 7.13, \mathrm{PaCO}, 59.9, \mathrm{PaO}_{2} 52.8, \mathrm{BE}-1 \mathrm{I}$ in the second). At the same time. creatine phosphokinase levels showed $8400 \mathrm{u}^{-1} \mathrm{~L}^{-1}$ in the first case and $4369 \mathrm{u} \cdot \mathrm{L}^{-1}$ in the second. Serum and urine myoglobin concentrations were $334.2 \mathrm{ng} \cdot \mathrm{ml}^{-1}$ and $1085 \mathrm{ng} \cdot \mathrm{ml}^{-1}$, and $468 \mathrm{ng} \cdot \mathrm{ml}^{-1}$ and 885 $\mathrm{ng} \cdot \mathrm{ml}{ }^{\prime}$, respectively. Efforts to cool the patients using alcohol were made. Following dantrolene $(400 \mathrm{mg}$ and 200 $\mathrm{mg}$ ). the hyperthermia. acidosis, hypoxaemia and hypercarbia subsided (temperature 37.5 and $37.5^{\circ} \mathrm{C} . \mathrm{PaO}_{2} 220$ $\mathrm{mmHg}$ and $180 \mathrm{mmHg}$ with $100 \%$ oxygen, $\mathrm{PaCO}, 35 \mathrm{mmHg}$ and $41 \mathrm{mmHg}$ respectively). Postoperatively, 20 $\mathrm{mg} \cdot \mathrm{hr}^{\prime}$ dantrolene infusion were administered for $24 \mathrm{hr}$. In the first case, an anaphylactoid reaction was confirmed by increased plasma tryptase.

Conclusion: We report two cases of hyperthermia after cardiac surgery in whom dantrolene was very effective in reducing the high rectal temperature.

Objectif : Rapporter deux cas d'hyperthermie survenus après une chinurgie cardiaque.

Éléments cliniques : La neutralisation de l'héparine était accomplie avec de la protamine administrée après l'arrêt de la circulation extracorporelle. Par la suite, de l'hypotension, de l'hypertension pulmonaire et de l'hypoxie apparaissaient. L'administration de méthylprednisolone et de catécholamine permettait de corriger l'hypotension induite par la protamine. Après ce traitement, la température rectale augmentait à $42^{\circ} \mathrm{C}$ dans le premier cas et à $40^{\circ} \mathrm{C}$ dans le deuxième. La gazométrie artérielle révélait, sous oxygène pur, une acidose et une hypercapnie sévères $\left(\mathrm{pH} 6.96, \mathrm{PaCO}_{2} 73 \mathrm{mmHg}, \mathrm{PaO}_{2} 45 \mathrm{mmHg}\right.$. BE -18 dans le premier cas et $\mathrm{pH} 7,23 . \mathrm{PaCO}_{2} 59,9$. $\mathrm{PaO}, 52.8$ et $\mathrm{BE}-1 /$ dans le second). En même temps, la créatine phosphokinase atteignait $8400 \mathrm{u} \cdot \mathrm{L}^{-1}$ dans le premier cas et $4369 \mathrm{u} \cdot \mathrm{L}$ ' dans le second. Les concentrations sériques et urinaires de myoglobine étaient respectivement de $334.2 \mathrm{ng} \cdot \mathrm{ml}^{-1}$ et de $1085 \mathrm{ng} \cdot \mathrm{ml}^{-1}$ dans le premier cas et de $468 \mathrm{ng} \cdot \mathrm{ml}^{-1}$ et de $885 \mathrm{ng} \cdot \mathrm{ml}^{-1}$ dans le second. Le refroidissement était entrepris avec de l'alcool. Après l'administration de dantrolène sodium. (400 et $200 \mathrm{mg}$ ). l'hyperthermie, l'acidose. l'hypoxémie, l'hypercarbie et l'hypertension rentraient dans l'ordre (température $37.5^{\circ} \mathrm{C}$ dans les deux cas, et respectivement, $\mathrm{PaO}_{2} 200 \mathrm{mmHg}$ et $180 \mathrm{mmHg}$ sous $100 \% \mathrm{O}_{2} . \mathrm{PaCO}_{2}$ $35 \mathrm{mmHg}$ et $41 \mathrm{mmHg}$ ). Du dantrolène sodium $20 \mathrm{mg}^{-1}{ }^{-1}$ était administré pendant $24 \mathrm{~h}$. Dans le premier cas. l'augmentation de la tryptase plasmatique confirmait la réaction anaphylactoïde.

Conclusion : Le dantrolène sodium a permis de réduire une température rectale élevée après une chirurgie cardiaque chez deux patients.

From the Department of Anaesthesiology, Osaka University Medical School and Department of Cardiovascular Surgery, Sakurabashi Watanabe Hospital.*

Address correspondence to: Dr. Kazuo Abe, Department of Anacsthesiology, Osaka University Medical School. 2-2 Yamadaoka, Suita, Osaka 565, Japan; Phone: 81-6-879-3133; Fax: 81-6-879-3139; E-mail: abe@anes.med.osaka-u.ac.jp Accepted for publication March 14, 1997. 
$\mathrm{T}$

HERE are reports ${ }^{1,2}$ of anaphylactoid reactions, including hyperthermic episodes, to protamine after the end of extracorporeal circulation during cardiac surgery. On the other hand, malignant hyperthermia (MH) is an inherited disorder of skeletal muscle that is catastrophic. Anaesthetic drugs that can trigger $\mathrm{MH}$ include halothane, enflurane, isoflurane, desflurane, sevoflurane as well as succinylcholine. The diagnosis of $\mathrm{MH}$ depends on a clinical and laboratory features represented by a hypermetabolic state within skeletal muscle. However, it is difficult to confirm the diagnosis of MH during cardiac surgery because of the hyperdynamic state. We report two cases of hyperthermia occurring after protamine induced hypotension.

\section{Case report \\ Case \#1}

A 64-yr-old, $169 \mathrm{~cm}, 70-\mathrm{kg}$ man was scheduled for mitral valve replacement and subaortic myectomy for hypertrophic obstructive cardiomyopathy (HOCM). Medical history included diabetes mellitus treated with diet and oral hypoglycaemic agents until four months earlier, when NPH insulin was added.

The patient was premedicated with $0.4 \mathrm{mg}$ atropine sulfate and $50 \mathrm{mg}$ hydroxyzine $\mathrm{im}$. Monitors included ECG, radial artery line, pulmonary artery catheter (thermodilution catheter. Baxter Edward Swan Ganz Model), pulse oximeter, capnograph, rectal temperature. Anaesthesia was induced with $15 \mathrm{mg}$ diazepam, $0.5 \mathrm{mg}$ fentanyl and muscle relaxation with $8 \mathrm{mg}$ vecuronium, and maintained with $100 \%$ oxygen, 70 $\mu \mathrm{g} \cdot \mathrm{kg}^{-1}$ fentanyl and pancuronium. After induction of anaesthesia, a transoesophageal echocardiography probe was inserted. Cardiac output and mixed venous oxygen saturation were continuously monitored using Vigilance Monitor Model VGS (Baxter USA). Mitral valve replacement and subaortic myectomy were performed. Cardiopulmonary bypass (CPB) time was 160 min and aortic clamp time was 105 min. Rewarming was accomplished over $\mathbf{3 0}$ min using high pump flows with subsequent weaning from $\mathrm{CPB}$ at a rectal temperature of 37.0. Ten minutes after CPB, systolic arterial blood pressure (SABP) was $100 \mathrm{mmHg}$, heart rate 80 beats. $\mathrm{min}^{-1}$, central venous pressure (CVP) $12 \mathrm{mmHg}$, pulmonary artery pressure (PAP) $22 / 14 \mathrm{mmHg}$, pulmonary capillary wedge pressure (PCWP) $14 \mathrm{mmHg}$, cardiac output (CO) was $5.4 \mathrm{~L} \cdot \mathrm{min}^{-1}$, mixed venous oxygen saturation was $75 \%$ under continuous infusion of $0.1 \mu \mathrm{g} \cdot \mathrm{kg}^{-1} \cdot \mathrm{min}^{-1}$ noradrenaline and $5 \mu \mathrm{g} \cdot \mathrm{kg}^{-1} \cdot \mathrm{min}^{-1}$ dopamine. About $20 \mathrm{~min}$ after $\mathrm{CPB}, 150 \mathrm{mg}$ protamine (protamine sulphate, $10 \mathrm{mg} \cdot \mathrm{ml}^{-1}$, Shimizu) were administered slowly via the central vein. Within $10 \mathrm{~min}$,
SABP decreased from 110 to $50 \mathrm{mmHg}, \mathrm{CVP}$ increased from 12 to $20 \mathrm{mmHg}$, PAP increased from $22 / 12$ to $65 / 45 \mathrm{mmHg}$, PCWP increased from 12 to $33 \mathrm{mmHg}$, and $\mathrm{CO}$ decreased from 5.0 to $2.2 \mathrm{~L} \cdot \mathrm{min}^{-1}$. Heart rate was maintained at about 110 beats $\mathrm{min}^{-1}$ under atrial pacing. Arterial blood gas analysis revealed; $\mathrm{pH} 7.20, \mathrm{PaCO}_{2} 46.1 \mathrm{mmHg}, \mathrm{PaO}_{2} 60 \mathrm{mmHg}, \mathrm{BE}$ 11 , oxygen saturation $\left(\mathrm{SaO}_{2}\right) 91 \%$. Based on these observations, an anaphylactoid reaction was suspected and methylprednisolone $(500 \mathrm{mg}$ ) was injected. Blood was sampled about one hour after protamine and centrifuged, and the serum was frozen for later tryptase measurement. In order to treat pulmonary hypertension, $0.02 \mu \mathrm{g} \cdot \mathrm{kg}^{-1} \cdot \mathrm{min}^{-1}$ prostaglandin $\mathrm{E}_{1}\left(\mathrm{PGE}_{1}\right)$ was infused and, PAP decreased from 65 to $30 \mathrm{mmHg}$, PCWP from 35 to 12, but hypotension (SABP 50-60 $\mathrm{mmHg}$ ) and low cardiac output (CO 2.2-2.5 L $\mathrm{min}^{-1}$ ) continued despite $0.2 \mu \mathrm{g} \cdot \mathrm{kg}^{-1} \cdot \mathrm{min}^{-1}$ noradrenaline and $7 \mu \mathrm{g} \cdot \mathrm{kg}^{-1} \cdot \mathrm{min}^{-1}$ dopamine infusion. Dopamine and $\mathrm{PGE}_{1}$ were discontinued. About $10 \mathrm{~min}$ after discontinuation of these drugs, $S A P$ increased to $100 \mathrm{mmHg}$, $\mathrm{CO}$ increased to $4.0 \mathrm{~L} \cdot \mathrm{min}^{-1}$ and $\mathrm{SaO}_{2}$ recovered to $100 \%$. Infusion of $60 \mathrm{mg} \cdot \mathrm{hr}^{-1}$ lidocaine was started for the treatment of premature ventricular contraction. Myoglobinuria developed and rectal temperature increased from 37.0 to $41^{\circ} \mathrm{C}$ within $60 \mathrm{~min}$ of the start of lidocaine. The SABP decreased to $50 \mathrm{mmHg}, \mathrm{CO}$ decreased to $2.0 \mathrm{~L} \cdot \mathrm{min}^{-1}$ and PAP increased to 70 $\mathrm{mmHg}$, and mixed venous oxygen saturation decreased from $85 \%$ to $50 \%$. Arterial blood gas analysis revealed hypoxaemia, hypercarbia and severe metabolic acidosis (pH 6.96, $\mathrm{PaCO}_{2} 73 \mathrm{mmHg}, \mathrm{PaO}_{2} 45 \mathrm{mmHg}, \mathrm{BE}-18$ with $100 \%$ oxygen). Creatine phosphokinase (CPK) concentration was $8400 \mathrm{u} \cdot \mathrm{L}^{-1}$. Serum myoglobin and urine myoglobin concentrations were $334.2 \mathrm{ng} \cdot \mathrm{ml}^{-1}$ (normal value; $23-30 \mathrm{ng} \cdot \mathrm{ml}^{-1}$ ) and $1085 \mathrm{ng} \cdot \mathrm{ml}^{-1}$ (normal; none). Malignant hyperthermia was suspected. Dantrolene $400 \mathrm{mg}$ was injected and surface cooling using alcohol was commenced. About $60 \mathrm{~min}$ after dantrolene injection, rectal temperature decreased to 37.5 and, while breathing $100 \%$ oxygen, $\mathrm{PaO}_{2}$ returned to $220 \mathrm{mmHg}$ and $\mathrm{PaCO}_{2}$ to $35 \mathrm{mmHg}$. Haemodynamic variables recovered (CO increased to $4.0 \mathrm{~L} \cdot \mathrm{min}^{-1}$, SAP increased to $100 \mathrm{mmHg}$, PAP decreased to $25 \mathrm{mmHg}$ and mixed venous oxygen saturation increased to $85 \%$ ). On postoperative day one, serum and urine myoglogin concentrations were 197.6 $\mathrm{ng} \cdot \mathrm{ml}^{-1}$ and $313 \mathrm{ng} \cdot \mathrm{ml}^{-1}$. Postoperatively, a dantrolene infusion of $20 \mathrm{mg} \cdot \mathrm{hr}^{-1}$ was administered for $24 \mathrm{hr}$ in the intensive care units. Tracheostomy was performed on the third postoperative day for the anticipated long term ventilatory support. Although the patient had been stable, haemodynamically, hepatic and renal failure 
developed. Serum tryptase concentration was 18.0 $\mathrm{ng} \cdot \mathrm{ml}^{-1}$ (normal $<2.0 \mathrm{ng} \cdot \mathrm{ml}^{-1}$, RIA method, Mitsubishi Yuka BCL, Osaka Japan).

\section{Case \#2}

A $69-y r-o l d, 162 \mathrm{~cm}, 67-\mathrm{kg}$ man was scheduled for total arch replacement and coronary artery bypass graft to right coronary artery (4 PD) for thoracic aortic aneurysm (DeBakey type 1) and coronary artery disease (\#1 90\% stenosis, \#2 90\% stenosis, \#4 50\% stenosis). Medical history included diabetes mellitus treated with diet and an oral hypoglycaemic until six months earlier, when NPH insulin had been added.

The patient was premedicated with $0.4 \mathrm{mg}$ atropine sulphate and $50 \mathrm{mg}$ hydroxyzine $\mathrm{im}$. Monitors included ECG, radial artery and pulmonary artery catheters, pulse oximeter, capnograph, and rectal temperature. Anaesthesia was induced with $15 \mathrm{mg}$ diazepam, 0.5 $\mathrm{mg}$ fentanyl and $8 \mathrm{mg}$ vecuronium bromide, and maintained with $100 \%$ oxygen, $40 \mu \mathrm{g} \cdot \mathrm{kg}^{-1}$ fentanyl and pancuronium. After induction, a transoesophageal echocardiography probe was inserted. Cardiac output and mixed venous oxygen saturation were continuously monitored using Vigilance Monitor Model VGS(Baxter USA). Anaesthesia time was $615 \mathrm{~min}$ and operation time was 480 min.

Cardiopulmonary bypass time was $130 \mathrm{~min}$. Rewarming was accomplished over 30 min using high pump flows with subsequent weaning from $\mathrm{CPB}$ at a rectal temperature of $37.0^{\circ} \mathrm{C}$. At $10 \mathrm{~min}$ after $\mathrm{CPB}$, SABP was $110 \mathrm{mmHg}$, heart rate was 96 beats. $\mathrm{min}^{-1}$, CVP was $8 \mathrm{mmHg}, \mathrm{PAP}$ was $25 / 12 \mathrm{mmHg}$, PCWP was $9 \mathrm{mmHg}$, $\mathrm{CO}$ was $3.4 \mathrm{~L} \cdot \mathrm{min}^{-1}$, mixed venous oxygen saturation was $84 \%$ under continuous infusion of $0.1 \mu \mathrm{g} \cdot \mathrm{kg}^{-1} \cdot \mathrm{min}^{-1}$ adrenaline, $10 \mu \mathrm{g} \cdot \mathrm{kg}^{-1} \cdot \mathrm{min}^{-1}$ dopamine and dobutamine. About $20 \mathrm{~min}$ after CPB, protamine (protamine sulfate, $10 \mathrm{mg} \cdot \mathrm{ml}^{-1}$, Shimizu) $170 \mathrm{mg}$ were administered slowly via the central vein. Within $10 \mathrm{~min}$, SABP decreased to $60 \mathrm{mmHg}$, CVP increased to $24 \mathrm{mmHg}$, PAP increased to $75 / 45$ $\mathrm{mmHg}, \mathrm{PCWP}$ increased to $43 \mathrm{mmHg}$, CO decreased to $1.9 \mathrm{~L} \cdot \mathrm{min}^{-1}$. Arterial blood gas analysis revealed; $\mathrm{pH} 7.29, \mathrm{PaCO}_{2} 47.2 \mathrm{mmHg}, \mathrm{PaO}_{2} 54.8 \mathrm{mmHg}, \mathrm{BE}$ -7 , oxygen saturation $\left(\mathrm{SaO}_{2}\right) 90 \%$. An anaphylactoid reaction was suspected and methylprednisolone (500 $\mathrm{mg}$ ) was given. Within an hour, the rectal temperature increased to $40^{\circ} \mathrm{C}$. Arterial blood gas analysis revealed hypoxaemia, hypercarbia and severe metabolic acidosis ( $\mathrm{pH} 7.13, \mathrm{PaCO}_{2} 59.9 \mathrm{mmHg}, \mathrm{PaO}_{2} 52.8 \mathrm{mmHg}$, $\mathrm{BE}-11$ with $100 \%$ oxygen). The CPK concentration was $4369 \mathrm{u} \cdot \mathrm{L}^{-1}$. Serum myoglobin and urine myoglobin levels were $468 \mathrm{ng} \cdot \mathrm{ml}^{-1}$ and $885 \mathrm{ng} \cdot \mathrm{ml}^{-1}$. Malignant hyperthermia was suspected. Dantrolene sodium, $200 \mathrm{mg}$, was given and surface cooling using alcohol was commenced. About $60 \mathrm{~min}$ after dantrolene, rectal temperature decreased to $37.5^{\circ} \mathrm{C}$ and breathing $100 \%$ oxygen, $\mathrm{PaO}_{2}$ returned to 180 $\mathrm{mmHg}$ and $\mathrm{PaCO}_{2}$ to $41 \mathrm{mmHg}$. At postoperative day one, CPK levels reduced to $1194 \mathrm{u} \cdot \mathrm{L}^{-1}$. Postoperatively, a dantrolene infusion of $20 \mathrm{mg} \cdot \mathrm{hr}^{-1}$ was administered for $24 \mathrm{hr}$ in the intensive care units. At the fifth postoperative day, tracheostomy was done for long term ventilatory support.

\section{Discussion}

In these two patients, hyperthermia developed after recovery from protamine induced hypotension. Myoglobinuria, high serum myoglobin concentration, high rectal temperature, increased CPK concentration, hypoxaemia, metabolic acidosis and hypercapnia suggested the possibility of $\mathrm{MH}$, but we could not confirm the diagnosis. There are many possible causes of hyperthermia, hypoxaemia, hypercapnia and increase of enzyme concentrations in patients after cardiac surgery. Catastrophic reactions to protamine are rare $(0.13 \%)^{3}$ but in patients with diabetes mellitus treated with NPH insulin which contains protamine, the incidence is $\mathbf{5 0}$ times greater than in the nondiabetic population. ${ }^{2}$ In our cases, the patient had been treated with NPH insulin (10-20 U.day $\left.{ }^{-1}\right)$ and appeared to have developed allergy to protamine before surgery. Serum tryptase is an indicator of mast cell involvement and anaphylactoid reaction. ${ }^{4,5}$ The increased serum tryptase concentration observed one hour after the protamine injection in this case, together with hypotension, hypovolaemia, pulmonary hypertension, hypoxaemia and hypercarbia suggested an anaphylactoid reaction. In the second case, serum tryptase concentration was not measured, so we could not confirm the diagnosis of anaphylactoid reaction to protamine. These patients developed hyperthermia after recovery from protamine induced hypotension.

Malignant hyperthermia is a genetically predisposed, potentially fatal disorder triggered by anaesthetic agents. ${ }^{6}$ Early diagnosis and treatment of $\mathrm{MH}$ is necessary, but when the patient is undergoing $C P B$, $\mathrm{MH}$ may be difficult to recognize. In our first case, hyperthermia developed after the administration of lidocaine. Previously, it was believed that amide local anaesthetics, such as lidocaine, could trigger $\mathrm{MH}^{7}$ but they do not. An infusion of lidocaine $2 \%$ was started after CPB for the treatment of arrhythmia and lidocaine $1 \%$ had been injected several times for local anaesthesia in cardiac catheterization before surgery when the patient's condition was stable. In the first case, sevoflurane $1 \%$ was administered for about 20 
min before $\mathrm{CPB}$ to control hypertension. In the second case, sevoflurane $1 \%$ was administered for two hours before CPB. There are some reports of sevoflurane induced $\mathrm{MH}^{8,9}$ In both of the present cases, sevoflurane was administered before $\mathrm{CPB}$, so that sevoflurane is unlikely to have been a trigger of hyperthermia in either case. Diagnosis of MH during and after CPB may be difficult because of the hypermetabolic state induced by extracorporeal circulation. Rewarming following hypothermic CPB may produce conditions similar to $\mathrm{MH}$ episodes in the postoperative period with rapid increases in temperature and carbon dioxide production. ${ }^{10,11}$ It is not possible to determine whether these cases are of $\mathrm{MH}$ or rewarming following hypothermic CPB. Since muscle biopsy testing was not undertaken, clinical features must be used to assess the likelihood of an $\mathrm{MH}$ episodes. Hypercapnia may be attributed to inadequate ventilation. Elevation of CPK concentration and myoglobinuria may accompany cardiac surgery. Although there are several possibilities for hyperthermia and increased serum enzyme concentration, the combination of hyperthermia, acidosis, myoglobinuria, elevated CPK, and temperature reduction after dantrolene support the clinical diagnosis of $\mathrm{MH}$. Dantrolene, a directly acting skeletal muscle relaxant, interrupts skeletal muscle hypermetabolism by uncoupling calcium transport from myofibrilla contraction. Administration of dantrolene early in an $\mathrm{MH}$ episode generally halts the progression of this syndrome. ${ }^{12}$

In conclusion, we report two cases of hyperthermia which developed after recovery from anaphylactoid reactions to protamine during cardiac surgery. Although the diagnosis of $\mathrm{MH}$ could not be confirmed, dantrolene was effective in reducing the high rectal temperatures.

\section{References}

1 Takenoshita $M$, Sugiyama $M$, Okuno $Y$, Inagaki $Y$, Yosbiya I, Shimazaki $\Upsilon$. Anaphylactoid reaction to protamine confirmed by plasma tryptase in a diabetic patient during open heart surgery. Anesthesiology 1996; 84: 233-5.

2 Levy JH, Zaidan JR, Faraj B. Prospective evaluation of risk of protamine reactions in patients with NPH insulin-dependent diabetics. Anesth Analg 1986; 65: 739-42.

3 Stewart WJ, McSweeney SM, Kellett MA, Faxon DP, Ryan TJ. Increased risk of severe protamine reactions in NPH insulin-dependent diabetics undergoing cardiac catheterization. Circulation 1984; 70: 788-92.

4 Schwartz LB, Tunginger JW, Miller J, Bokbari $R$, Dull $D$. Time course of appearance and disappearance of human mast cell tryptase in the circulation after anaphylaxis. J Clin Invest 1989; 83: 1551-5.

5 Laroche D, Vergnaud $M-C$, Sillard B, Soufarapis $H$, Bricard $H$. Biochemical markers of anaphylactoid reactions to drugs. Anesthesiology 1991; 75: 945-9.

6 Britt $B A$. Recent advances in malignant hyperthermia. Anesth Analg 1972; 51: 841-50.

7 Gronert GA. Malignant hyperthermia Anesthesiology 1980; 53: 395-423.

8 Ducart $A$, Adnet $P$, Renaud B, Riou B, Krivosic-Horber $R$. Malignant hyperthermia during sevoflurane administration Anesth Analg 1995; 80: 609-11.

9 Ochiai $R$, Toyoda $Y$, Nishio $I$, et al. Possible association of malignant hyperthermia with sevoflurane anesthesia. Anesth Analg 1992; 74: 616-8.

10 Allen $G C$, Cattran $C B$. Rewarming following hypothermic cardiopulmonary bypass in the malignant hyperthermia-susceptible patient: implications for diag nosis and perioperative management Can J Anaesth 1989; 36: 81-5.

11 Sladen $R N$. Temperature and ventilation after hypothermic cardiopulmonary bypass. Anesth Analg 1985; 64: 816-20.

12 Kolb ME, Horne ML, Martz R. Dantrolene in human malignant hyperthermia. Anesthesiology 1982; 56: 254-62. 